\title{
PENGARUH FREKUENSI DAN KONSENTRASI AUKSIN ALAMI \\ TERHADAP PERTUMBUHAN DAN HASIL TANAMAN KEDELAI \\ (Glycine Max L. Merril).
}

\section{EFFECT OF FREQUENCY AND NATURAL AUXIN CONCENTRATION ON GROWTH AND YIELD OF SOYBEAN (Glycine Max L. Merril).}

\author{
Selvia Juliana, Yukiman Armadi \\ Mahasiswa dan Dosen Agroteknologi Fakultas Pertanian dan Peternakan Universitas \\ Muhammadiyah Bengkulu \\ Email: selviajuliana@gmail.com
}

\begin{abstract}
Di provinsi Bengkulu terjadinya peningkatan hasil produksi masih belum mencukupi kebutuhan di provisi itu sendiri, penelitian ini bertujuan untuk mengetahui Pengaruh Frekuensi Dan Konsentrasi Auksin Alami Terhadap Pertumbuhan Dan Hasil Tanaman Kedelai (Glycine Max L. Merril). penelitian ini telah dilaksanakan di Jl. Danau Raya No.59, Panorama, Singaran Pati, Kota Bengkulu, Pada ketinggian tempat 30 meter di atas permukaan laut. Menggunakan rancangan acak lengkap (RAL) faktorial dengan 2 faktor yaitu faktor pertama frekuensi pemberian auksin alami (A): A1 (1 kali 14 HST), A2: (2 kali 14 dan 28 HST), A3: (3 kali 14, 28 dan 42 HST), sedangkan faktor kedua adalah Konsentrasi Auksin Alami (B): B0 (Kontrol), B1 (1,0 ml/liter), B2 (1,5 ml/liter), dan B3 (2,0 $\mathrm{ml} /$ liter). Masing-masing perlakuan diulang sebanyak 4 kali. Hasil data dianalisis menggunakan Analisis Sidik Ragam (ANOVA) dan apabila berbeda nyata dilakukan uji lanjut Duncan's Multiple Range Test (DMRT) taraf 0,5\%. Hasil perlakuan frekuensi menunjukkan pengaruh yang sangat nyata terhadap tinggi tanaman, berat kering tanaman dan berat 100 biji, berpengaruh nyata terhadap jumlah daun, jumlah cabang dan berat basah tanaman Kedelai (Glycine Max L. Merril). Sedangkan perlakuan konsentrasi pada hasil penelitian ini adalah yang berpengaru nyata terhadap jumlah daun, berat kering tanaman dan jumlah polong tanaman Kedelai (Glycine Max L. Merril), pada penelitian ini tidak menunjukkan adanya interaksi antar frekuensi dan konsentrasi auksin alami terhadap tanaman kacang kedelai.
\end{abstract}

Kata kunci : Kedelai, auksin alami, Frekuensi, Konsentrasi.

\section{BAB I. PENDAHULUAN}

\subsection{Latar belakang Kedelai} (Glycine max L. Merril) merupakan komoditas pangan utama ketiga setelah padi dan jagung dan merupakan yang terpenting karena kaya protein nabati yang diperlukan untuk peningkatan gizi masyarakat. Protein nabati ini selain aman gizi kesehatan juga relatif murah dibandingkan sumber pangan (tahu, tempe, kecap, susu kedelai, tauco dan sebagainya) (Permadi, 2014).
Badan pusat statistik di Bengkulu menyatakan bahwa penduduk di Bengkulu mengalami peningkatan pada tahun 2016 yaitu 359.488 jiwa dan pada tahun 2017 yaitu 368.065 jiwa. Pada tahun 2017 naik 2,33\% dibandingkan tahun 2016. Peningkatan itu terjadi sebanyak 8.577 jiwa sehingga kebutuhan kedelainya pun meningkat seiring bertambahnya jumlah penduduk kebutuhan akan kedelai terus meningkat namun produksi kedelai di Bengkulu terus mengalami 
penurunan sehingga Bengkulu harus mengimpor kedelai dari luar Bengkulu seperti Jawa dan Lampung demi mencukupi kebutuhan kedelai di Bengkulu.

https://bengkulukota.bps.go.id/, (2017)

Berdasarkan data yang diperoleh di BPS (2017), jumlah produksi kedelai secara nasional pada tahun 2017 sebanyak 538.728 ton, sangat jauh sekali mengalami penurunan dari tahun sebelumnya (2016) yaitu sebanyak 859.653 ton. Begitupun juga yang dialami provinsi Bengkulu sangat jauh drastis mengalami penurunan. Dari tahun 2016 produksi di Bengkulu sebanyak 4.664 ton, di tahun 2017 produksi kedelai di Bengkulu hanya mencapai 413 ton (http:/antarabengkulu.com, 2015). Untuk dapat memenuhi kebutuhan kedelai, begkulu mengandalkan impor dari luar provinsi seperti provinsi Lampung dan Jawa yang dimana provinsi kedelai di provinsi Lampung dan Jawa lebih besar dari Bengkulu, yakni sebanyak 9.960 ton (BPS, 2016). Kedelai merupakan salah satu protein nabati dengan kandungan 39\%, dimana $2 \%$ dari seluruh rakyat Indonesia memperoleh sumber protin dari kedelai. Jumlah kebutuhan kedelai untuk konsumsi tergantung dari jumlah penduduk dan konsumen per kapita, sehingga laju pertumbuhan produk harus diimbangi dengan laju peningkatan hasil produksi. Penurunan produksi kedelai di Bengkulu diakibatkan oleh penurunan luas lahan panen hal ini dikarenakan para penduduk enggan menanam kedelai yang tingkat penghasilannya lebih rendah dibandingkan dengan hasil

padi..(https://bengkulu.antaranews.co $\mathrm{m} /$ berita/32236/bps-produksi-kedelai bengkulu-meningkat-7028-ton, 2015).

Zat pengatur tumbuh merupakan sekumpulan senyawa organik atau hormon tumbuh yang memiliki daya rangsangan terhadap tanaman. Zat pengatur tumbuh biasanya yang tercipta secara endogen oleh tanaman itu sendiri maupun secara eksogen yang di bentuk oleh manusia dalam bentuksintetis, zat pengatur tumbuh terdiri atas golongan auksin dan sitokinin (Lestari, 2012). Zat pengatur tumbuh merupakan senyawa yang dalam konsentrasi rendah dapat memacu pertumbuhan tanaman, zat pengatur tumbuh yang di tambahkan dapat memanipulasi pertumbuhan dan perkembangan tanaman yang mengarah pada peningkatan kualitas dan kuantitas benih kedelai, pembesaran ukuran biji dan memperbaiki kandungan gizi seperti lemak dan protein (Mareza 2009, dalam Podesta, dkk. 1997).

Auksin alami untuk memacu pertumbuhan akar baru perlu diberikan zpt. Auksin juga berfungsi untuk merangsang proses perkecambahan biji. Saat ini sudah banyak produk-produk zpt baik yang alami maupun sintetis. Namun kita bisa juga membuat zpt sendiri dengan mudah dan hemat tentunya. Salah satu cara adalah dengan menggunakan umbi bawang merah. Bawang merah dengan kandungan auksin dan giberelin yang cukup tinggi bisa kita gunakan sebagai sumber zpt alami.Hormon auksin berfungsi untuk merangsang pembesaran sel, sintesis DNA kromosom. Gunanya adalah untuk merangsang pertumbuhan akar, 
misalnya pada stekan atau cangkokan (Marfirani, 2014).

Zat pengaatur tumbuh (ZPT) dibuat agar tanaman memacu pembentukan fitohormon (hormon tumbuhan). Dengan demekian fitohormon sebagai senyawa organik yang bekerja aktif dalam jumlah sedikit, ditransformasikan keseluruh bagian tanaman sehingga dapat mempengaruhi pertumbuhan atau proses-proses fisiologi tanaman (Nurlaeni, 2015).Salah satu tumbuhan yang dianggap dapat digunakan sebagai zat pengatur tumbuh alami adalah bawang merah (Allium cepa L.). Karena bawang merah memiliki kandungan hormon pertumbuhan berupa hormon auksin dan giberellin, sehingga dapat memacu pertumbuhan

benih (Marfirani, 2014).

Penggunaan ZPT yaitu untuk memacu terbentuknya perakaran, tunas/cabang, daun, bunga dan buah. Ada beberapa macam dan bagian pada tumbuhan yang mengandung zpt alami yaitu air kelapa, dan berbagai jenis tanaman lainnya. Pemberian zat perangsang tumbuh (ZPT) yang dapat merangsang pertumbuhan akar dapat dilakukan. Banyak bukti menyatakan bahwa auksin berpengaruh terhadap pertumbuhan batang dan akar.(Artanti,2007)

Air kelapa mengandung zat

pengatur tumbuh auksin dan sitokinin. Auksin dapat

merangsang pertumbuhan dengan cara pemanjangan sel dan menyebabkan dominasi ujung, sedangkan sitokinin merangsang pertumbuhan dengan cara pembelahan sel. Di dalam air kelapa juga terdapat zat pembangun lainnya seperti protein, lemak, mineral, karbohidrat bahkan lengkap dengan vitamin C dan B kompleks (Susilo, 1996). Hasil penelitian yang sudah di teliti pada tanaman komuditi lain, melati putih (Jasminum sambac L.) menyatakan hormonal dalam air kelapa yang sudah diketahui adalah Ausin mencapai $60 \%$ dan sitokinin mencapai $20 \%$. Penelitian tentang ZPT alami pernah dilakukan terhadap tanaman Melati Putih (Jasminum sambac L.) yang menggunakan dari ekstak bawang merah pada kosentrasi $1,5 \%$ (15 cc/liter air), berbeda nyata pada pertumbuhan akar dan tunas. ( Hamdani, dkk. 2013).

Pemberian air kelapa dengan perlakuan $60 \quad \%$ mampu meningkatkan rerata jumlah daun terbanyak yaitu 4,50 helai daun yang berbeda nyata dengan kontrol dan perlakuan lainnya, rerata berat basah tajuk yaitu 2,37 gram yang berbeda nyata dengan perlakuan kontrol dan perlakuan $40 \%$ namun tidak berbeda nyata dengan perlakuan $20 \%$. Berat kering tajuk juga menunjukkan bahwa perlakuan \% berbeda nyata dengan kontrol dan perlakuan lainnya dengan nilai rerata 2,37 gram. Tanaman stek pada perlakuan kontrol menghasilkan jumlah daun, berat basah tajuk terendah. (Mukarlina,dkk. 2013).

Pemberian ekstrak bawang merah $70 \%$ memberikan hasil nilai terbaik terhadap semua parameter pertumbuhan akar stek batang bawah mawar, yaitu panjang akar stek $(8,95$ $\mathrm{cm})$, jumlah akar stek (13,75 buah), berat basah akar stek (1,93 gr), dan berat kering akar stek $(0,43$ gr $)$. (Alimudin, 2017).Berdasarkan uraian di atas perlu dilakukan penelitian 'Pengaruh Frekuensi dan 
Konsentrasi Auksin Alami Terhadap Pertumbuhan dan Hasil Tanaman Kedelai (Glycine Max L. Merrill). Frekuensi pemberian dan konsentrasi rhizobakteri

memberikan interaksi pada komponen pertumbuhan tinggi tanaman dan jumlah daun, tetapi tidak menunjukkan adanya interaksi pada komponen hasil. Frekuensi pemberian rhizobakteri sebanyak satu kali dengan konsentrasi $10 \%$ menunjukkan tinggi tanaman lebih tinggi $(39,25 \mathrm{~cm})$ dan jumlah daun lebih banyak $(14,25$ helai/tanaman) dari perlakuan yang lain. Perbandingan perlakuan rhizobakteri dengan SOP PT.

Mitratani dua tujuh diketahui bahwa perlakuan rhizobakteri menunjukkan jumlah polong yang lebih banyak tetapi mempunyai ukuran polong yang lebih kecil dari pada SOP, selain itu tanaman yang diberikan perlakuan rhizobakteri mempunyai tingkat serangan hama dan penyakit yang lebih rendah dari pada SOP dan tanaman yang tidak diberi rhizobakteri (Mufti, 2015).

\subsection{Tujuan Penelitian}

Tujuan penelitian ini untuk mengetahui pengaruh frekuensi dan konsentrasi dan auksin alamiterhadappertumbuhan dan hasil tanaman kedelai (Glycine max $L$.

Merrill ).

\subsection{Hipotesis penelitian}

1. Frekuensi pemberian auksin alami berpengaruh terhadap hasil tanaman kedelai( Glycine max L. Merrill ).

2. Konsentrasi auksin alami berpengaruh terhadap hasil tanaman kedelai(Glycine max L. Merrill).
3. Interaksiantara frekuensi dan konsentrasi auksin alami tidak berpengaruh terhadap hasil tanaman

kedelai(Glycine max L. Merrill).

\section{BAB III. METODOLOGI PENELITIAN}

Penelitian ini dilaksanakan di J1. Danau Raya No.59, Panorama, Singaran Pati, Kota Bengkulu, Pada ketinggian tempat $24 \mathrm{Mdpl}$,yang dilaksanakan pada bulan November 2019 sampai Februari 2020.

Penelitian ini dilaksanakan dengan menggunakan Rancangan Acak Lengkap (RAL) disusun secara faktorial. Terdiri dari 2 Faktor yaitu: Faktor pertama adalah FrekuensiPemberian Auksin Alami:

A1 $=1$ kali (14 HST)

A2 $=2 \operatorname{kali}(14$ dan 28 HST $)$

A3=3kali(14, 28 dan 42 HST) Faktor ke dua yaitu Konsentrasi Auksin

Alami:

$\mathrm{B} 0=$ Kontrol

$\mathrm{B} 1=1,0 \mathrm{ml} /$ literair

$\mathrm{B} 2=1,5 \mathrm{ml} /$ liter air

$\mathrm{B} 3=2,0 \mathrm{ml} / \mathrm{liter}$ air

Dari perlakuan ini terdapat 12 kombinasi perlakuan yang diulang sebanyak 4 kali ulangan sehingga terdapat $\quad 48$ kombinasi perlakuansehingga setiap satuan percobaan terdapat 4 tanaman, sehingga di peroleh 19 2unit tanaman.

\section{BAB IV. HASIL DAN \\ PEMBAHASAN}

\subsection{Hasildan Pembahasan}


Hasil analisis keragaman untuk masing-masing faktor dan interaksinya terdapat

Tabel 5.

Hasil analisis parameter yang diamati yaitu dapat dilihat pada tabel 5 .

keragaman pengaruh frekuensi dan konsentrasi auksin alami terhadap semua parameter yang diamati. 
Parameter yang diamati

F-hitung

$\mathrm{KK}(10$

Frekuensi

Konsentrasi

Interaksi

$0 \%)$

Tinggi tanaman 14 hst

$0.70 \mathrm{tn}$

0.13 tn

$0.47 \mathrm{tn}$

11.20

Tinggi tanaman 28 hst

$2.46 \mathrm{tn}$

$0.73 \mathrm{tn}$

$1.54 \mathrm{tn}$

11.23

Tinggi tanaman 42 hst

$5.80 * *$

$0.02 \mathrm{tn}$

$1.98 \mathrm{tn}$

9.41

Tinggi tanaman 56 hst

$1.66 \mathrm{tn}$

$1.38 \mathrm{tn}$

$0.76 \mathrm{tn}$

8.41

Jumlah daun 14 hst

$1.52 \mathrm{tn}$

$0.26 \mathrm{tn}$

$1.24 \mathrm{tn}$

11.28

Jumlah daun 28 hst

$4.04 *$

$3.12 *$

$2.17 \mathrm{tn}$

8.01

$3.75 *$

$3.43 *$

$1.29 \mathrm{tn}$

8.64

1.30 tn

$1.09 \mathrm{tn}$

$0.58 \mathrm{tn}$

6.04

Jumlah cabang 28 hst

$1.93 \mathrm{tn}$

$1.16 \mathrm{tn}$

$1.12 \mathrm{tn}$

26.37

0.69 tn

$1.13 \mathrm{tn}$

16.28

$3.41 *$

$1.06 \mathrm{tn}$

$1.22 \mathrm{tn}$

9.42

0.38 tn

$0.59 \mathrm{tn}$

$1.59 \mathrm{tn}$

1.53

$4.07 *$

$0.83 \mathrm{tn}$

$0.16 \mathrm{tn}$

20.62

Berat kering tanaman

$9.53 * *$

$0.48 \mathrm{tn}$

$2.71 \mathrm{tn}$

10.07

$0.50 \mathrm{tn}$

$1.63 \mathrm{tn}$

19.26

Jumlah polong cipo

0.75 tn

$3.54 *$

0.47 tn

24.09

Berat polong basah

$1.24 \mathrm{tn}$

$0.27 \mathrm{tn}$

1.55 tn

15.58

0.74 tn

$0.80 \mathrm{tn}$

$1.04 \mathrm{tn}$

13.83

Berat 100 biji

$9.79 * *$

$1.93 \mathrm{tn}$

$1.58 \mathrm{tn}$

17.77

Jumlah bintil

$0.44 \mathrm{tn}$

$0.58 \mathrm{tn}$

32.67

Keterangan :

$0.99 \mathrm{tn}$

tn : Tidak Berbeda Nyata $*$ : Berbeda

nyata

** : Berbeda sangat nyata

KK : Koenfisien Keragaman

\subsubsection{Tinggi Tanaman}

Hasil pengamatan rata-rata tinggi tanaman kedelai dapat dilihat pada lampiran 8, 9.Hasil analisis keragaman menunjukkan bahwa perlakuan frekuensi memberikan pengaruh nyata. Pemberian

konsentrasi tidak memberikan pengaruh nyata. Dan interaksi antara kedua perlakuan menunjukkan tidak berpengaruh nyata pada tinggi tanaman. Hasil uji DMRT frekuensi dan konsentrasi auksin alami dapat dilihat pada tabel 6 . 
Tabel 6.Pengaruh frekuensi dan konsentrasi auksin alami terhadap tinggi tanaman kedelai $(\mathrm{cm})$ umur $42 \mathrm{HST}$.

\begin{tabular}{ccccc} 
Konsentrasi Auksin & \multicolumn{3}{c}{ Frekuensi/Pengaplikasian } & Pengaruh \\
Alami & A1 & A2 & A3 & $\begin{array}{c}\text { utama } \\
\text { Konsentrasi }\end{array}$ \\
\cline { 2 - 4 } & 1 kali & $2 \mathrm{kali}$ & $3 \mathrm{kali}$ & 52.13 \\
\hline B0=kontrol & 51.13 & 54.88 & 50.38 & 52.46 \\
B1=1,0 ml/liter air & 48.38 & 58.50 & 50.50 & 52.29 \\
B2=1,5 m1/liter air & 46.38 & 57.63 & 52.88 & 51.91 \\
B3=2,0 ml/liter air & 51.50 & 50.00 & 54.25 & \\
Pengaruh utama & $49.34 \mathrm{~b}$ & $55.25 \mathrm{a}$ & $52.00 \mathrm{ab}$ &
\end{tabular}

Frekuensi

Keterangan : angka-angka yang diikuti oleh huruf yang sama pada baris tidak berbeda nyata dengan uji DMRT pada taraf 5\%.

Berdasarkan uji lanjut DMRT perlakuan FrekuensiA1 pemberian 1 kaliberbeda nyata terhadap perlakuan frekuensi A2 pemberian 2 kali dan tidak berbeda nyata terhadap perlakuan frekuensi A3 pemberian 3 kali. Perlakuan frekuensi A2 pemberian 2 kali tidak berbeda nyata terhadap perlakuan A3 pemberian 3 kali.

\subsubsection{Jumlah Daun}

Hasil pengamatan rata-rata jumlah daun kedelai dapat dilihat pada lampiran 18,19. Hasil analisis keragaman menunjukkan bahwa perlakuan frekuensi memberikan pengaruh nyata. Pemberian konsentrasi memberikan pengaruh nyata. Dan interaksi antara kedua perlakuan menunjukkan tidak berpengaruh nyata pada jumlah daun. Hasil uji DMRT konsentrasi dapat dilihat pada tabel 7 .

Tabel 7. Pengaruh frekuensi dan konsentrasi auksin alami terhadap jumlah daunkedelai (helai) umur 42 HST.

\begin{tabular}{ccccc}
$\begin{array}{c}\text { Konsentrasi Auksin } \\
\text { Alami }\end{array}$ & \multicolumn{3}{c}{ Frekuensi/Pengaplikasian } & $\begin{array}{c}\text { Pengaruh } \\
\text { utama }\end{array}$ \\
& 1 kali & 2 kali & 3 kali & Konsentrasi \\
& & & & \\
\hline B0=kontrol & 10.13 & 11.88 & 10.75 & $10.92 \mathrm{~b}$ \\
B1=1,0 ml/liter air & 10.88 & 12.13 & 11.25 & $11.42 \mathrm{ab}$ \\
B2=1,5 m1/liter air & 11.13 & 12.75 & 12.38 & $12.08 \mathrm{a}$ \\
B3= 2,0 m1/liter air & 12.13 & 11.50 & 12.00 & $11.87 \mathrm{a}$ \\
Pengaruh utama & $11.06 \mathrm{~b}$ & $12.06 \mathrm{a}$ & $11.59 \mathrm{ab}$ &
\end{tabular}

Keterangan : angka-angka yang diikuti oleh huruf yang sama pada baris tidak berbeda nyata dengan uji DMRT pada taraf 5\%. 
Berdasarkan uji lanjut DMRT frekuensi A2 pemberian 2 kali dan perlakuan Frekuensi A1 pemberian 1 tidak berbeda nyata terhadap kaliberbeda nyata terhadap perlakuan perlakuan frekuensi A3 pemberian 3

kali. Perlakuan frekuensi 27,28. Hasil analisis keragaman A2 pemberian 2 kali tidak menunjukkan bahwa perlakuan berbeda nyata terhadap perlakuan A3 frekuensi memberikan pengaruh pemberian 3 kali.

Berdasarkan uji DMRT perlakuan nyata. Pemberian konsentrasi tidak memberikan pengaruh nyata. Dan

Konsentrasi Auksin Frekuensi/Pengaplikasian

Alami A1 A2

A3

Pengaruh 1 kali 2 kali utama Konsentrasi

\begin{tabular}{lcccc}
\hline B0=kontrol & 6.88 & 6.63 & 7.00 & 6.83 \\
B1=1,0 ml/liter air & 6.63 & 7.50 & 7.25 & 7.12 \\
B2=1,5 ml/liter air & 6.25 & 7.63 & 7.25 & 7.04 \\
B3=2,0 ml/liter air & 7.00 & 7.13 & 7.38 & 7.17 \\
Pengaruh utama & $6.69 \mathrm{~b}$ & $7.22 \mathrm{a}$ & $7.22 \mathrm{a}$ & \\
$\quad$ Frekuensi & & & &
\end{tabular}

Keterangan : angka-angka yang diikuti oleh huruf yang sama pada baris tidak berbeda nyata dengan uji DMRT pada taraf 5\%.

konsentrasi B0 tidak berbeda nyata terhadap perlakuan konsentrasi B1 dan berbeda nyata terhadap perlakuan konsentrasi B2 dan B3. Perlakuan konsentrasi B1 tidak berbeda nyata terhadap perlakuan konsentrasi B2 dan B3. Perlakuan konsentrasi B2 tidak berbeda nyata terhadap perlakuan konsentrasi B3.

4.1.3. Jumlah Cabang Hasil pengamatan rata-rata jumlah cabang dapat dilihat pada lampiran

Berdasarkan uji lanjut DMRT perlakuan Frekuensi A1 pemberian 40 perlakuan frekuensi $\mathrm{A} 3$ pemberian 41 terhadap perlakuan pemberiankali.

kaliberbeda nyata terhadap perlakuan frekuensi A2 pemberian 2 kali dan kali. Perlakuan frekuensi A2 pemberian 2 kali tidak berbeda nyata interaksi antara kedua perlakuan menunjukkan tidak berpengaruh nyata pada jumlah cabang. Hasil uji DMRT konsentrasi dapat dilihat pada tabel 8. Tabel 8. Pengaruh frekuensi dan konsentrasi auksin alami terhadap jumlah cabang (cabang) kedelai umur 56 HST.

\subsubsection{Umur Bunga Hasil} pengamatan rata-rata umur berbunga dapat dilihat pada lampiran 30,31.

Hasil analisis keragaman menunjukkan bahwa perlakuan frekuensi tidak memberikan pengaruh nyata. Pemberian konsentrasi tidak memberikan pengaruh nyata. Dan interaksi antara kedua perlakuan menunjukkan tidak berpengaruh nyata 


\section{AGRICULTURE}

pada umur berbunga. Hasil analisis keragaman umur berbunga dapat dilihat pada tabel 9.

keragaman menunjukkan bahwa perlakuan frekuensi memberikan pengaruh nyata. Pemberian

Tabel 9. Analisis ragam Umur berbunga.

\begin{tabular}{|c|c|c|c|c|c|c|}
\hline Sumber & Derajat & Jumlah & Kuadrat & F-Hitung & \multicolumn{2}{|c|}{ F-tabel } \\
\hline Keragaman & $\begin{array}{c}\text { Bebas } \\
\text { (df) }\end{array}$ & $\begin{array}{c}\text { Kuadrat } \\
\text { (SS) }\end{array}$ & $\begin{array}{l}\text { Tengah } \\
\text { (MS) }\end{array}$ & & $5 \%$ & $1 \%$ \\
\hline Frekuensi & 2 & 0.21 & 0.1 & $0.38 \mathrm{tn}$ & 3.32 & 5.39 \\
\hline Konsentrasi & 3 & 0.7 & 0.23 & $0.83 \mathrm{tn}$ & 2.92 & 4.51 \\
\hline Interaksi & 6 & 2.69 & 0.44 & $1.59 \mathrm{tn}$ & 2.42 & 3.47 \\
\hline Galat & 36 & 10.12 & 0.28 & & & \\
\hline Total & 47 & 13.75 & & & & \\
\hline
\end{tabular}

Secara uji analisis keragaman pada umur berbunga semua perlakuan dan interaksi tidak berpengaruh nyata namun rata-rata umur berbunga pada perlakuan frekuensi A2 dan konsentrasi auksin

\begin{tabular}{ll}
\hline Perlakuan & Umur berbunga \\
\hline A1 $=1$ kali & 34.53 \\
A2 $=2$ kali & 34.59 \\
A $3=3$ kali & 34.56
\end{tabular}

Perlakuan frekuensi A2 (2 kali) memberikan hasil tertinggi yaitu 34.59. Tabel 11. Rata-rata umur berbunga pada perlakuan dengan konsentrasi.

\begin{tabular}{ll}
\cline { 2 - 2 } Perlakuan & Umur berbunga \\
\hline B0 $=$ Kontrol & 34.58 \\
B1 $=1,0 \mathrm{ml} /$ liter air & 34.46 \\
B2 $=1,5 \mathrm{ml} /$ liter air & 34.79 \\
B3 $=2,0 \mathrm{ml} /$ liter air & 34.42 \\
\hline
\end{tabular}

Perlakuan kombinasi konsentrasi B2 (1,5 ml/liter air) memberikan hasil tertinggi yaitu 34.79 .

4.1.5. Berat Basah Tanaman Hasil pengamatan rata-rata berat basah tanaman dapat dilihat pada lampiran 32,33. Hasil analisis alami B2. Rata-rata umur berbunga dapat dilihat pada tabel 10 dan 11 . pada perlakuan frekuensi auksin alami. 


\section{AGRICULTURE}

konsentrasi dapat dilihat pada tabel 12.

Berdasarkan uji lanjut DMRT perlakuan Frekuensi A1 pemberian 1 kaliberbeda nyata terhadap perlakuan frekuensi A2 pemberian 2 kali dan Berdasarkan uji lanjut DMRT terhadap perlakuan A3 pemberian 3 kali.

\subsubsection{Berat Kering Tanaman}

Hasil pengamatan rata-rata berat kering tanaman kedelai dapat dilihat bahwa perlakuan frekuensi memberikan pengaruh nyata. Pemberian konsentrasi memberikan pengaruh nyata. Dan interaksi antara kedua perlakuan menunjukkan tidak

perlakuan frekuensi A3 pemberian 3

Tabel 12. Pengaruh frekuensi dan konsentrasi auksin alami terhadap berat basah tanaman kedelai.

Konsentrasi Auksin

Alami

B0=kontrol
$\mathrm{B} 1=1,0 \mathrm{ml} /$ liter air
$\mathrm{B} 2=1,5 \mathrm{ml} /$ liter air
$\mathrm{B} 3=2,0 \mathrm{ml} /$ liter air
Pengaruh utama

A1 $\begin{array}{ll}\text { Frekuensi/Pengaplikasian } \\ \text { A2 }\end{array}$

1 kali

2 kali

151.25

151.88

158.00

134.50

$148.90 \mathrm{a}$
123.13

128.38

120.25

122.00

$123.44 \mathrm{~b}$
A3

3 kali

128.13

134.38

125.38

119.75

$126.91 \mathrm{~b}$
Pengaruh utama

Konsentrasi

134.17

138.21

134.54

125.41

Frekuensi

Keterangan : angka-angka yang diikuti oleh huruf yang sama pada baris tidak berbeda nyata dengan uji DMRT pada taraf 5\%.

perlakuan Frekuensi A1 pemberian 1 kaliberbeda nyata terhadap perlakuan frekuensi A2 pemberian 2 kali dan perlakuan frekuensi A3 pemberian 3 kali. Perlakuan frekuensi A2 pemberian 2 kali tidak berbeda nyata pada lampiran 35, 36. Hasil

analisis keragaman menunjukkan berpengaruh nyata pada berat kering tanaman. Hasil uji DMRT konsentrasi dapat dilihat pada tabel 13. Tabel 13. Pengaruh frekuensi dan konsentrasi auksin alami terhadap berat kering tanaman kedelai.
Konsentrasi Auksin

Alami
Frekuensi/Pengaplikasian

$\begin{array}{ccc}\text { A1 } & \text { A2 } & \text { A3 } \\ 1 \text { kali } & 2 \text { kali } & 3 \text { kali }\end{array}$

Pengaruh utama Konsentrasi 


\begin{tabular}{ccccc}
\hline B0=kontrol & 35.50 & 34.75 & 27.13 & $32.46 \mathrm{a}$ \\
B1=1,0 m1/liter air & 29.00 & 29.50 & 27.75 & $28.75 \mathrm{~b}$ \\
B2=1,5 ml/liter air & 32.00 & 29.00 & 29.38 & $30.12 \mathrm{ab}$ \\
B3= 2,0 ml/liter air & 36.88 & 29.25 & 30.00 & $32.04 \mathrm{a}$ \\
Pengaruh utama & $33.34 \mathrm{a}$ & $30.62 \mathrm{~b}$ & $28.56 \mathrm{~b}$ &
\end{tabular}

Frekuensi

Keterangan : angka-angka yang diikuti oleh huruf yang sama pada baris tidak berbeda nyata dengan uji DMRT pada taraf $5 \%$.

kali. Perlakuan perlakuan konsentrasi B3. 4.1.7. frekuensi A2 pemberian 2 kali Jumlah Polong tidak berbeda nyata

Tabel 14. Pengaruh frekuensi dan konsentrasi auksin alami terhadap jumlah polong kedelai.

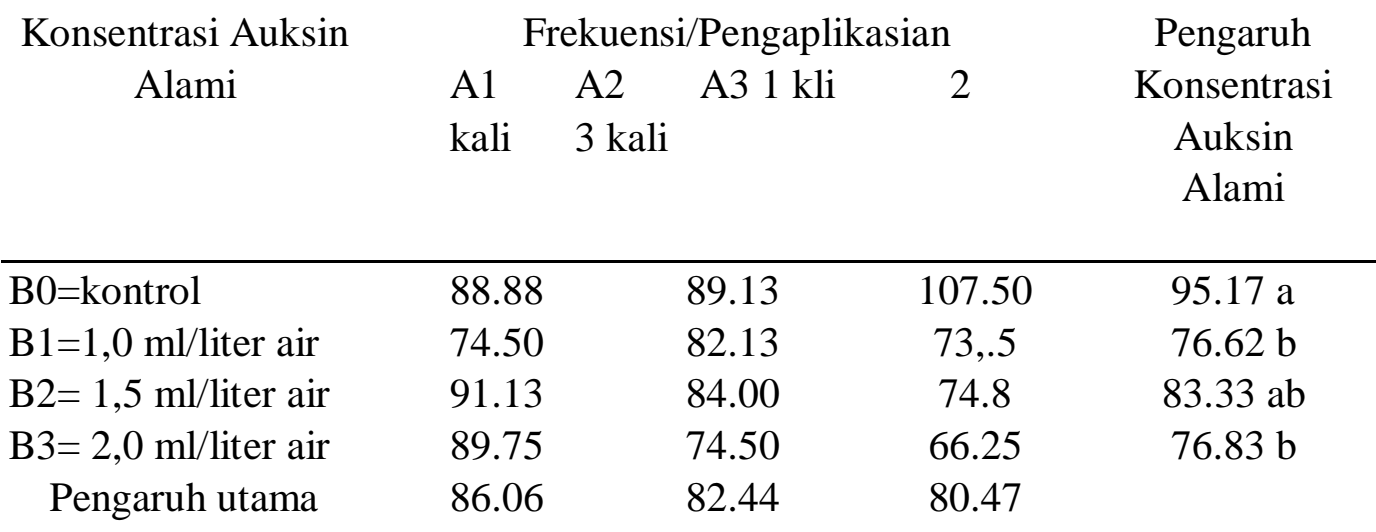

Frekuensi

Keterangan : angka-angka yang diikuti oleh huruf yang sama pada baris tidak berbeda nyata dengan uji DMRT pada taraf $5 \%$.

berbeda nyata dengan perlakuan

terhadap perlakuan A3 pemberian 3 konsentrasi B2 Perlakuan konsentrasi kali.

Berdasarkan uji lanjut DMRT perlakuan konsentrasi B0 berbeda nyata terhadap perlakuan konsentrasi B1 dan tidak berbeda nyata terhadap perlakuan konsentasi dan B3. Perlakuan konsentrasi B1 tidak berbeda nyata terhadap perlakuan konsentrasi B2tetapi berbeda nyata dengan B3. Perlakuan konsentrasi B2 tidak berbeda nyata terhadap Berdasarkan uji lanjut DMRT perlakuan konsentrasi B0 berbeda nyata terhadap perlakuan konsentrasi B1 dan perlakuan B3 tetapi tidak B1 tidak berbeda nyata terhadap perlakuan konsentrasi B2 dan B3. Perlakuan konsentrasi B2 tidak berbeda nyata terhadap perlakuan konsentrasi B3. 4.1.8. Jumlah Polong Cipo Hasil pengamatan ratarata jumlah polong cipo dapat dilihat pada Hasil pengamatan rata-rata jumlah polong kedelai dapat dilihat pada lampiran 38, 39. Hasil analisis keragaman menunjukkan bahwa perlakuan frekuensi tidak memberikan pengaruh nyata. Pemberian konsentrasi memberikan pengaruh nyata. Dan interaksi antara 


\section{AGRICULTURE}

kedua perlakuan menunjukkan tidak berpengaruh nyata pada jumlah polong. Hasil uji DMRT konsentrasi dapat dilihat pada tabel 14.

lampiran 41, 42. Hasil analisis keragaman menunjukkan bahwa perlakuan frekuensi tidak memberikan pengaruh nyata. Pemberian konsentrasi tidak memberikan pengaruh nyata. Dan interaksi antara kedua perlakuan menunjukkan tidak berpengaruh nyata pada jumlah polong cipo. Hasil analisis keragaman jumlah polong cipo dapat dilihat pada tabel 15 . 
Tabel 15.Analisis ragam Jumlah polong cipo.

\begin{tabular}{|c|c|c|c|c|c|c|}
\hline \multirow{2}{*}{$\begin{array}{c}\text { Sumber } \\
\text { Keragaman }\end{array}$} & \multirow{2}{*}{$\begin{array}{l}\text { Derajat } \\
\text { Bebas }\end{array}$} & \multirow{2}{*}{$\begin{array}{l}\text { Jumlah } \\
\text { Kuadrat }\end{array}$} & \multirow{2}{*}{$\begin{array}{l}\text { Kuadrat } \\
\text { Tengah }\end{array}$} & \multirow[t]{2}{*}{ F-Hitung } & \multicolumn{2}{|c|}{ F-tabel } \\
\hline & & & & & $5 \%$ & $1 \%$ \\
\hline & (df) & (SS) & (MS) & & & \\
\hline Frekuensi & 2 & 9.44 & 4.72 & $0.75 \mathrm{tn}$ & 3.32 & 5.39 \\
\hline Konsentrasi & 3 & 5.22 & 1.74 & $0.27 \mathrm{tn}$ & 2.92 & 4.51 \\
\hline Interaksi & 6 & 17.88 & 2.98 & $0.47 \mathrm{tn}$ & 2.42 & 3.47 \\
\hline Galat & 36 & 224.31 & 6.23 & & & \\
\hline Total & 47 & 256.86 & & & & \\
\hline
\end{tabular}

Secara uji analisis keragaman pada jumlah polong cipo semua perlakuan dan interaksi tidak berpengaruh nyata namun ratarata jumlah polong cipo pada perlakuan frekuensi A1 dan konsentrasi auksin alami B0. Rata-rata Jumlah polong cipo dapat dilihat pada tabel 16 dan 17.

Tabel 16. Rata-rata Jumlah polong cipo pada perlakuan frekuensi auksin alami

\begin{tabular}{lc}
\hline Perlakuan & Jumlah polong cipo \\
\hline A1 = 1 kali & 10.78 \\
A2 =2 kali & 9.75 \\
A3 =3 kali & 10.56 \\
\hline
\end{tabular}

Perlakuan frekuensi A1 (1 kali) memberikan hasil tertinggi yaitu 10.78.

Tabel 17. Rata-rata Jumlah polong cipo pada perlakuan dengan konsentrasi.

\begin{tabular}{lc}
${ } }$ & Jumlah polong cipo \\
\hline B0= Kontrol & 10.87 \\
B1=1,0 ml/liter air & 10.00 \\
B2=1,5 ml/liter air & 10.17 \\
B3=2,0 ml/liter air & 10.42
\end{tabular}


Perlakuan kombinasi konsentrasi B0 (kontrol) memberikan hasil tertinggi

4.1.9. Berat Polong Basah Hasil yaitu 10.87. pengamatan rata-rata berat polong

basah dapat dilihat pada lampiran 43, 44. Hasil analisis keragaman menunjukkan bahwa perlakuan frekuensi tidak memberikan

Pemberian konsentrasi tidak pengaruh nyata. memberikan pengaruh nyata. Dan interaksi antara kedua perlakuan menunjukkan tidak berpengaruh

Tabel 18.Analisis ragamberat polong basah.

\begin{tabular}{|c|c|c|c|c|c|c|}
\hline \multirow{3}{*}{$\begin{array}{c}\text { Sumber } \\
\text { Keragaman }\end{array}$} & \multirow{3}{*}{$\begin{array}{c}\text { Derajat } \\
\text { Bebas } \\
\text { (df) }\end{array}$} & \multirow{3}{*}{$\begin{array}{c}\text { Jumlah } \\
\text { Kuadrat } \\
\text { (SS) }\end{array}$} & \multirow{3}{*}{$\begin{array}{c}\text { Kuadrat } \\
\text { Tengah } \\
\text { (MS) }\end{array}$} & \multirow[t]{3}{*}{ F-Hitung } & \multicolumn{2}{|c|}{ F-tabel } \\
\hline & & & & & $5 \%$ & $1 \%$ \\
\hline & & & & & & \\
\hline Frekuensi & 2 & 203.62 & 101.81 & $1.24 \mathrm{tn}$ & 3.32 & 5.39 \\
\hline Konsentrasi & 3 & 197.1 & 65.7 & $0.80 \mathrm{tn}$ & 2.92 & 4.51 \\
\hline Interaksi & 6 & 760.95 & 126.82 & $1.55 \mathrm{tn}$ & 2.42 & 3.47 \\
\hline Galat & 36 & 2935.62 & 81.54 & & & \\
\hline Total & 47 & 4097.31 & & & & \\
\hline
\end{tabular}

Secara uji analisis keragaman pada berat polong basah semua perlakuan dan interaksi tidak berpengaruh nyata namun rata-rata berat polong basah pada perlakuan frekuensi A2 dan konsentrasi auksin Perlakuan

\section{ta-rata berat $\mathrm{p}$}

pada tabel 19

20.

Rata-rata b

basah padi perlakuan $\underline{\text { auksin alami }}$

kuensi
A1 = 1 kali
56.00
A $2=2$ kali
60.88
A3 =3 kali
57.00

Perlakuan frekuensi A2 (2 kali) memberikan hasil tertinggi yaitu 60.88. 


\section{Jurnal AGRICULTURE}

Tabel 20. Rata-rata berat polong basah pada perlakuan dengan konsentrasi.

\begin{tabular}{lc}
\cline { 2 - 2 } Perlakuan & berat polong basah \\
\hline $\mathrm{B} 0=$ Kontrol & 57.08 \\
$\mathrm{~B} 1=1,0 \mathrm{ml} /$ liter air & 57.38 \\
$\mathrm{~B} 2=1,5 \mathrm{ml} /$ liter air & 56.29 \\
$\mathrm{~B} 3=2,0 \mathrm{ml} /$ liter air & 61.08 \\
\hline
\end{tabular}

Perlakuan kombinasi konsentrasi B3 (2,0 ml/liter air) memberikan hasil nyata pada berat polong basah. Hasil analisis keragaman berat polong basah dapat dilihat pada tabel 18. keragaman berat biji kering/tanaman tertinggi yaitu 61.08. dapat dilihat pada tabel 21.

\begin{tabular}{lc}
\hline Perlakuan & Berat biji kering/tanaman \\
\hline A1 $=1$ kali & 34.09 \\
A2 $=2$ kali & 35.97 \\
A3 $=3$ kali & 35.87 \\
\hline
\end{tabular}

Perlakuan frekuensi A3 (3 kali) memberikan hasil tertinggi yaitu 35.87.

Tabel 23. Rata-rata Berat biji kering/tanaman pada perlakuan dengan konsentrasi.

Perlakuan Berat biji kering/tanaman

\begin{tabular}{ll}
$\mathrm{B} 0=$ Kontrol & 36.83 \\
$\mathrm{~B} 1=1,0 \mathrm{ml} /$ liter air & 36.29 \\
$\mathrm{~B} 2=1,5 \mathrm{ml} /$ liter air & 32.46 \\
$\mathrm{~B} 3=2,0 \mathrm{ml} /$ liter air & 35.66 \\
\hline
\end{tabular}

Perlakuan kombinasi konsentrasi B0 (kontrol) memberi

21. Analisis ragam $b$

\begin{tabular}{|c|c|c|c|c|c|c|}
\hline \multirow{2}{*}{$\begin{array}{c}\text { Sumber } \\
\text { Keragaman }\end{array}$} & \multirow{2}{*}{$\begin{array}{c}\text { Derajat } \\
\text { Bebas }\end{array}$} & \multirow{2}{*}{$\begin{array}{l}\text { Jumlah } \\
\text { Kuadrat }\end{array}$} & \multirow{2}{*}{$\begin{array}{l}\text { Kuadrat } \\
\text { Tengah }\end{array}$} & \multirow[t]{2}{*}{ F-Hitung } & \multicolumn{2}{|c|}{ F-tabel } \\
\hline & & & & & $5 \%$ & $1 \%$ \\
\hline & (df) & $(\mathrm{SS})$ & (MS) & & & \\
\hline Frekuensi & 2 & 35.71 & 17.85 & $0.74 \mathrm{tn}$ & 3.32 & 5.39 \\
\hline Konsentrasi & 3 & 138.52 & 46.17 & $1.93 \mathrm{tn}$ & 2.92 & 4.51 \\
\hline Interaksi & 6 & 149.32 & 24.88 & $1.04 \mathrm{tn}$ & 2.42 & 3.47 \\
\hline Galat & 36 & 858.25 & 23.84 & & & \\
\hline Total & 47 & 1181.81 & & & & \\
\hline
\end{tabular}




\subsubsection{Berat Biji Kering/Tanaman}

Hasil pengamatan rata-rata berat biji kering/tanaman dapat dilihat pada lampiran 45, 46. Hasil analisis keragaman menunjukkan bahwa perlakuan frekuensi tidak memberikan pengaruh nyata. Pemberian konsentrasi tidak memberikan pengaruh nyata. Dan interaksi antara kedua perlakuan menunjukkan tidak berpengaruh nyata pada berat biji kering/tanaman. Hasil analisis Secara uji analisis keragaman pada Berat biji kering/tanaman semua perlakuan dan interaksi tidak berpengaruh nyata namun ratarata berat biji

kering/tanamanpada perlakuan
frekuensi
A2 dan

konsentrasi auksin alami B0.

Ratarata berat biji kering/tanaman dapat dilihat pada tabel 22 dan 23.

Tabel 22. Rata-rata Berat biji kering/tanaman pada perlakuan frekuensi auksin

alami.

yaitu 36.83. 4.1.11.

\section{Berat 100 Biji}

Hasil pengamatan rata-rata berat 100 biji dapat dilihat pada lampiran 47, 48. Hasil analisis keragaman menunjukkan bahwa perlakuan frekuensi memberikan pengaruh nyata.Pemberian konsentrasi tidak memberikan pengaruh nyata. Dan interaksi antara kedua perlakuan menunjukkan tidak berpengaruh nyata pada tinggi berat 100 biji. Hasil uji DMRT konsentrasi dapat dilihat pada tabel 24 .

kaliberbeda nyata terhadap perlakuan frekuensi A2 pemberian 2 kali dan perlakuan frekuensi A3 pemberian 3 kali. Perlakuan frekuensi A2 pemberian 2 kali tidak berbeda nyata terhadap perlakuan A3 pemberian 3 kali. 


\section{9/ Jurnal AGRICULTURE}

4.1.12. Jumlah Bintil Akar Hasil pengamatan rata-rata Jumlah bintil akar kedelai dapat dilihat pada lampiran 50, 51. Hasil analisis keragaman menunjukkan bahwa perlakuan frekuensi tidak

Tabel 24. Pengaruh frekuensi dan konsentrasi auksin alami terhadap pertumbuhan dan hasil tanaman kedelai berat 100 biji.

Konsentrasi Auksin Alami Frekuensi/Pengaplikasian

Alami
B0=kontrol
$\mathrm{B} 1=1,0 \mathrm{ml} /$ liter air
$\mathrm{B} 2=1,5 \mathrm{ml} /$ liter air
$\mathrm{B} 3=2,0 \mathrm{ml} /$ liter air
Pengaruh utama
Frekuensi

\begin{tabular}{ccc}
\multicolumn{3}{c}{ Frekuensi/Pengaplikasian } \\
\hline $\mathrm{A} 1$ & $\mathrm{~A} 2$ & $\mathrm{~A} 3$ \\
$\underline{1 \mathrm{kali}}$ & $\underline{2 \mathrm{kali}}$ & $\underline{3 \mathrm{kali}}$ \\
18.25 & 18.38 & 16.63 \\
21.38 & 13.88 & 15.50 \\
19.88 & 16.50 & 12.63 \\
19.13 & 15.88 & 15.88 \\
$19.66 \mathrm{a}$ & $16.16 \mathrm{~b}$ & $15.16 \mathrm{~b}$
\end{tabular}
Pengaruh utama

$\underline{\text { Konsentrasi }}$

17.75

16.92

16.33

16.96

Keterangan : angka-angka yang diikuti oleh huruf yang sama pada baris tidak berbeda nyata dengan uji DMRT pada taraf $5 \%$.

\begin{tabular}{|c|c|c|c|c|c|c|}
\hline \multirow{2}{*}{$\begin{array}{c}\text { Sumber } \\
\text { Keragaman }\end{array}$} & \multirow{2}{*}{$\begin{array}{l}\text { Derajat } \\
\text { Bebas }\end{array}$} & \multirow{2}{*}{$\begin{array}{l}\text { Jumlah } \\
\text { Kuadrat }\end{array}$} & \multirow{2}{*}{$\begin{array}{l}\text { Kuadrat } \\
\text { Tengah }\end{array}$} & \multirow[t]{2}{*}{ F-Hitung } & \multicolumn{2}{|c|}{ F-tabel } \\
\hline & & & & & $5 \%$ & $1 \%$ \\
\hline & (df) & (SS) & (MS) & & & \\
\hline Frekuensi & 2 & 1.88 & 0.94 & $0.73 \mathrm{tn}$ & 3.32 & 5.39 \\
\hline Konsentrasi & 3 & 3.8 & 1.26 & $0.99 \mathrm{tn}$ & 2.92 & 4.51 \\
\hline Interaksi & 6 & 4.48 & 0.74 & $0.58 \mathrm{tn}$ & 2.42 & 3.47 \\
\hline Galat & 36 & 45.93 & 1.27 & & & \\
\hline Total & 47 & 56.11 & & & & \\
\hline
\end{tabular}

Berdasarkan uji lanjut DMRT Pemberian konsentrasi tidak perlakuan Frekuensi A1 pemberian 1 memberikan pengaruh nyata. Dan 
interaksi antara kedua perlakuan menunjukkan tidak berpengaruh nyata pada jumlah bintil akar. Hasil analisis keragaman jumlah bintil akar dapat dilihat pada tabel 25 .

tertinggi yaitu 3.92 .

\subsection{Pembahasan}

Pengaruh Frekuensi Dan

Konsentrasi Auksin Alami Terhadap

Secara uji analisis keragaman pada jumlah bintil akar semua perlakuan dan interaksi tidak berpengaruh nyata namun rata-rata jumlah bintil akar pada perlakuan frekuensi A1 dan konsentrasi auksin alami B3. Rata-rata jumlah bintil akar dapat dilihat pada tabel 26 dan 27.

Tabel 26. Rata-rata jumlah bintil akar pada perlakuan frekuensi auksin alami

\begin{tabular}{lc}
\hline Perlakuan & Jumlah bintil akar \\
\hline A1 $=1$ kali & 3.72 \\
A2 $=2$ kali & 3.50 \\
A3 =3 kali & 3.37 \\
\hline
\end{tabular}

Perlakuan frekuensi A1 (1 kali) memberikan hasil tertinggi yaitu 3.72.

Tabel 27. Rata-rata jumlah bintil akar pada perlakuan dengan konsentrasi.

Perlakuan Jumlah bintil akar

$\mathrm{B} 0=$ Kontrol 3.17

$\mathrm{B} 1=1,0 \mathrm{ml} / \mathrm{liter}$ air

$\mathrm{B} 2=1,5 \mathrm{ml} /$ liter air

B3=2,0 ml/liter air 3.92

Perlakuan kombinasi konsentrasi B3 (2,0 ml/liter air) memberikan hasil

Pertumbuhan Dan Hasil Tanaman Kedelai (Glycine Max L. Merril). Dari data analisis ragam pada perlakuan frekuensi pemberian umur berbunga, jumlah polong, jumlah polong cipo, berat polong basah, berat biji kering dan jumlah bintil akar. 
Sedangkan perlakuan

Konsentrasi auksin alami menunjukkan pengaruh nyata terhadap parameter jumlah daun 28 HST, jumlah daun 42 HST, berat kering tanaman dan jumlah polong. Sedangkan menunjukkan pengaruh yang tidak nyata terhadap parameter tinggi tanaman 14 HST, tinggi tanaman 28 HST, tinggi tanamn 42 HST, tinggi tanaman 56 HST, jumlah daun 14 HST, jumlah daun 56 HST, jumlah cabang $28 \mathrm{HST}$, jumah cabang 42 HST, jumlah cabang 56 HST, umur berbunga, berat basah tanaman, jumlah polong cipo, berat polong basah, berat biji kering, berat 100 biji dan jumlah bintil akar. Interaksi anatara keduanya menunjukkan tidak berpengaruh nyata terhadap semua parameter yang dilakukan.

Hasil uji DMRT (Duncan's Multiple Range Test) menunjukkan bahwa perlakuan frekuensi telah menunjukkan pengaruh yang sangat nyata terhadap tinggi tanaman. Pada perlakuan frekuensi (A2) pemberian 2 kali (52.25) tidak berbeda nyata dengan (A3) pemberian 3 kali (52.00)

dan berbeda nyata dengan

(A1) pemberian 1 kali (49.34).Diduga karena pemberian auksin alami berperan penting pada masa pertumbuhan vegetatif tanaman. Hal ini sejalan dengan penelitian Darwati, dkk (2017) auksin berperan dalam proses pemanjangan sel dan pertambahan sel sehingga menyebabkan tanaman bertambah tinggi.

Hasil uji DMRT (Duncan's

Multiple Range Test) menunjukkan bahwa perlakuan frekuensi telah menunjukkan pengaruh nyata terhadap jumlah daun. Pada perlakuan frekuensi (A2) pemberian 2 kali (12.06) tidak berbeda nyata dengan (A3) pemberian 3 kali (11.59) dan berbeda nyata dengan (A1) pemberian 1 kali (11.11). Diduga hal ini terjadi karena daun merupakan salah satu organ tanaman yang sangat penting terutama untuk fotosintesis agar tanaman dapat menghasilkan makanan dan mengalami pertumbuhan yang optimum. Hal ini sesuai dengan hasil penelitian Siswanto et al. (2010), menyatakan bahwa pemberian bawang merah dengan konsentrasi $1,5 \mathrm{ml} /$ liter memberikan hasil terbaik untuk pertumbuhan panjang tunas, jumlah daun, tingkat kehijauan daun pada tanaman kedelai.

Hasil uji DMRT (Duncan's Multiple Range Test) menunjukkan bahwa perlakuan frekuensi telah menunjukkan pengaruh nyata terhadap jumlah cabang. Pada perlakuan frekuensi (A2) pemberian 2 kali (7.22) dan (A3) pemberian 3 (7.22) berbeda nyata dengan frekuensi (A1) pemberian 1 kali

(6.69). Diduga hal ini terjadi karena kandungan ZPT dapat mempengaruhi dan meningkatkan pertumbuhan vegetatif dapat mempercepat pertumbuhan dan pembelahan sel sehingga meningkatkan jumlah cabang tanaman kedelai. Hal ini sejalan dengan pernyataanMiyasaka (2002)karena ketersedian auksin alami di dalam tanah mencukupi, sebagaimana telah di ketahui bahwa auksin alami memiliki unsure $\mathrm{N}$ untuk merangsang pertumbuhan secara keseluruhan, khususnya batang, cabang, dan daun.

Hasil uji DMRT (Duncan's 
Multiple Range Test) menunjukkan bahwa perlakuan frekuensi telah menunjukkan pengaruh nyata terhadap berat basah tanaman. Pada perlakuan frekuensi (A1) pemberian 1 kali (148.90) berbeda nyata dengan frekuensi (A3) pemberian 3 kali (126.91),juga berbeda nyata dengan (A2) pemberian 2 kali (123.44).

Hasil uji DMRT (Duncan's

Multiple Range Test) menunjukkan bahwa perlakuan frekuensi telah menunjukkan pengaruh yang sangat nyata terhadap berat kering tanaman. Pada perlakuan frekuensi (A1) pemberian 1 kali (33.34) berbeda nyata dengan frekuensi (A2) pemberian 2 kali (30.62) juga berbeda nyata dengan(A3) pemberian 3 kali (28.56). Diduga hal ini terjadi karena setiap peningkatan pemberian auksin alami yang diberikan akan meningkatkan jumlah unsur hara yang tersedia. Hal ini sejalan dengan penelitian Wattimena (1988) bahwa peningkatan perlakuan yang diberikan akan meningkatkan berat kering tanaman pada perlakuanfrekuensi auksinakan meningkatkan kandungan zat organik dan anorganik di dalam sel.

Hasil uji DMRT (Duncan's

Multiple Range Test) menunjukkan bahwa perlakuan frekuensi telah menunjukkan pengaruh nyata terhadap berat 100 biji. Pada perlakuan frekuensi (A1) pemberian 1 kali (19.66) berbeda nyata dengan frekuensi (A2) pemberian 2 kali (16.66), juga berbeda nyata dengan frekuensi (A3) pemberian 3 kali

(15.16). Diduga hal ini terjadi karena pengaruh konsentrasi auksin alami air kelapa. Hal ini sejalan dengan penelitian Gardnet, (2008), mengemukakan bahwa biji sebagian besar tanaman budiaya dan tanaman menyimpan karbohidrat dan lipid sebagai cadangan energi yang utama. Biji juga menyimpan protein, asam amino, dan subtansi lainnya.

Hasil uji DMRT (Duncan's

Multiple Range Test) menunjukkan bahwa perlakuan Konsentrasi telah menunjukkan pengaruh nyata terhadap jumlah daun. Pada perlakuan konsentrasi (B2) 1,5 $\mathrm{ml} /$ liter air (12.08) tidak berbeda nyata dengan (B3) $2,5 \mathrm{ml} /$ liter air (11.87)tidak berbeda nyata denga (B1) 1,0 ml/liter air 911.42) berbeda nyata dengan (B0) kontrol (10.92). Diduga karena dengan semakin tingginya akumulasi unsur hara dan fotosintat, mengakibatkan berat basah stek pucuk japonica juga meningkat. Hal ini sejalan dengan penelitian Suyati et.al. (2013) menyatakan bahwa akar merupakan organ penyerap unsure hara dan air dari media tanam yang banyak mengandung bahan organik ini sangat diperlukan oleh tumbuhan untuk mendukung pertumbuhan organ tanaman seperti akar, batang dan daun pertumbuhan organ tanaman yang baik akan meningkatkan kandungan berat basah tanaman stek pucuk.

Hasil uji DMRT (Duncan's

Multiple Range Test) menunjukkan bahwa perlakuan Konsentrasi telah menunjukkan pengaruh nyata terhadap berat kering tanaman. Pada perlakuan konsentrasi (B0) kontrol (32.46) tidak berbeda nyata dengan (B3) 2,0 ml/liter air (32.04) tidak berbeda nyata denga (B2) $1,5 \mathrm{ml} /$ liter air (30.12) berbeda nyata dengan (B1) $1,0 \mathrm{ml} /$ liter air (28.15). Berat kering 
tanaman mencerminkan akumulasi dari senyawa organik yang berhasil disentesis dari senyawa anorganik, terutama air dan karbondioksida dari unsur hara yang terserap dari hasil fotosintesis tanaman. Suryanti, Mukalina Rizalinda (2013).

Hasil uji DMRT (Duncan's

Multiple Range Test) menunjukkan bahwa perlakuan Konsentrasi telah menunjukkan pengaruh nyata terhadap jumlah polong. Pada perlakuan konsentrasi (B0) kontrol (95.17) tidak berbeda nyata dengan (B2) 1,5 ml/liter air (83.33) tidak berbeda nyata denga (B3) $2,0 \mathrm{ml} /$ liter air (76.83) berbeda nyata dengan (B1) 1,0 ml/liter air (76.62). Diduga karena tanaman akan lebih baik bila menggunakan jenis pupuk, dosis, cara dan watu pemberian yang tepat. Zahrah (2011).

Hasil penelitian menunjukkan bahwa perlakuan frekuensi auksin alami berpengaruh nyata terhadap tinggi tanaman, jumlah daun, jumlah cabang, berat basah tanaman, berat kering tanaman, berat 100 biji tanaman, dan perlakuan konsentrasi auksin alami berpengaruh nyata terhadap jumlah daun, berat kering tanaman, jumlah polong. serta interaksi keduanya berpengaruh tidak nyata. Dan hasil uji DMRT belum menunjukkan interaksi antara frekuensi dan konsentrasi (A1) 1 kali (14HST), frekuensi (A2) 2 kali (14 dan 28 HST), frekuensi (A3) 3 kali $(14,28$ dan 42 HST) dengan konsentrasi (B0) kontrol , (B1) 1,0 $\mathrm{ml} /$ liter air, (B2) 1,5 ml/liter air dan (A3) 2,0 $\mathrm{ml} / \mathrm{liter}$ air berpengaruh tidak nyata. Perlakuan frekuensi auksin alami berpengaruh nyata terhadap tinggi tanaman tertinggi pada (52.25 gr) pada perlakuan A2 dan terendah (49.34 gr) pada A1, jumlah daun tertinggi pada (12.06 helai) pada perlakuan A2 dan terendah (11.11 helai) pada A1, jumlah cabang pada tertinggi (7.22 cabang) pada perlakuan A2 dan terendah (6.69) pada A1, berat basah tanaman tertinggi (148.90 gr) pada perlakuan A1 dan terendah (123.44 gr) pada $\mathrm{A} 2$, berat kering tanaman tertinggi (33.34 gr) pada perlakuan A1 terendah (28.56 gr) pada A3, dan berat 100 biji tertinggi (19.66) pada perlakuan A1 dan terendah (15.16 gr) pada A3.

Sedangkan yang konsentrasi auksin alami berpengaruh nyata terhadap jumlah daun tertinggi (12.08 helai) pada perlakuan B2 terendah (10.92 helai) pada B0, berat kering tanaman tertinggi (32.46 gr) pada perlakuan B0 terendah $(28.15$ gr) pada B1 dan jumlah polong tertinggi (95.17 polong) pada perlakuan B0 terendah pada 976.62 polong) pada B1. Ini dikarenakan tanaman kedelai membutuhkan jumlah unsur hara yang berbeda setiap fase pertumbuhannya. Darmanik, dkk (2011) yang menyatakan bahwa tanaman membutuhkan jumlah unsur hara yang berbeda pada tiap fase pertumbuhannya. Umumnya, tanaman membutuhkan unsur hara dalam jumlah yang besar setelah melewati fase vegetatif menuju fase generatif. Hal ini didukung oleh Hakim (1986) menyatakan bahwa pertumbuhan tanaman akan lebih baik bila faktor yang mempengaruhi pertumbuhan seimbang dan member keuntungan. Bila faktor ini tidak dapat dikendalikan maka pertumbuhan yang diharapkan tidak dapat diperoleh. Hal ini tersebut di perkuat oleh Sitompul (1995) yang menyatakan bahwa untuk 
dapat berkembang dengan baik dan menyelesaikan siklus hidupnya secara lengkap, tanaman membutuhkan keadaan lingkungan tertentu yaitu keadaan lingkungan yang optimum untuk mengekpresikan program genetiknya secara penuh.

\section{BAB V. KESIMPULAN DAN SARAN 5.1. Kesimpulan}

Berdasarkan hasil analisis data dan pembahasan tentang Pengaruh Frekuensi dan Konsentrasi Auksin Alami Terhadap Pertumbuhan Dan Hasil Tanaman Kedelai (Glycine Max L. Merril). dapat disimpulkan bahwa:

1. Perlakuan frekuensi auksin alamimenunjukkan pengaruh yang nyata terhadap tinggi tanaman 42 HST, jumlah daun 42 HST, jumlah cabang 56 HST, berat basah tanaman, berat kering tanaman dan berat 100 biji.

2. Perlakuankonsentrasiauksin alami menunjukkan pengaruh yang nyata terhadap jumlah daun 42 HST, berat kering tanaman dan jumlah polong.

3. Pada penelitian ini tidak terjadi interaksi antarfrekuensi dan konsentrasi auksin alami.

\subsection{Saran Pada} penelitianPengaruh

Frekuensi dan Konsentrasi Auksin Alami Terhadap Pertumbuhan dan Hasil Tanaman Kedelai (Glycine Max L. Merril) disarankan untuk melakukan sebagai berikut yaitu:

$\begin{array}{lr}\text { 1. Sebaiknya } & \text { petani } \\ \text { menggunakan } & \text { auksin } \\ \text { alami untuk } & \text { menjaga } \\ \text { pertumbuhan tanaman } & \text { tansentrasi } \\ \text { dengan konsil } & \text { auksin alami dari hasi }\end{array}$

terbaik yaitu B2 (1,5 $\mathrm{ml} /$ liter air).

2. Perlu dilakukan penelitian lebih lanjut pada pemberian auksin alami dengan frekuensi yang lebih tinggi agar didapat hasil yang maksimal.

DAFTAR PUSTAKA AAK. 2000. Kedelai.

Kanisius.

Yogyakarta. Hal. 11-23. Adisarwanto. 2008. Budidaya Kedelai Tropika. Penebar Swadaya. Jakarta.

Hal. 7-14. Adisarwanto. 2014. Budidaya Kedelai Tropika. Penebar Swadaya.

Jakarta.

Hal. 5-25.

Alimudin, dkk. 2017. Aplikasi pemberian ekstrak bawang merah (Alium cepa L.) terhadap pertumbuhan akar stek batang bawah mawar (Rosa Sp.)varietas Malltic.

Anonim,2004.http://www.croplangen etics.com/soybean.asp?topic $=$ $4 \&$ sm $=$ diakses tanggal 20

Juli 2018.

Anonim. 2012. Mengenal zat pengatur tumbuh. http://lembahpinus.com/index 2.php?option=com_content \& do $\mathrm{pdf}=1 \& \mathrm{id}=124$, diakses Februari 2012.

Atman, 2014. Produksi Kedelai Strategi Meningkatkan Produksi Kedelai Melalui PTT. Graha Ilmu. Yogyakarta. 
Artanti, F.Y. 2007. Pengaruh Macam Pupuk Organik Cair dan

Konsentrasi IAA terhadap Pertumbuhan Setek Tanaman Stevia (Stevia rebaudiana Bertoni M.). Skripsi S1 FP UNS Surakarta. Dalam website:

https://eprints.uns.ac.id/2147/

Diakses pada tanggal

8 september 2015. Badan

Pusat Statistik, 2017. 'data produksi kacang kedelai", Bengkulu.

Cahyono,, B. 2007. Kedelai Teknik

Budidaya Dan Analisis Usaha tani. Aneka Ilmu.

Semarang.

Darwanti dkk, 2017.

Pengaruh auksin

terhadap pertumbuhan bibit cabutan alam gaharu

(Aquailaria malaccencis Lamk).

Darmanik, M. M. B., B. E Hasibuan,

Fauzi, Sarifuddin, Hamidah

Hanun. 2011.

Kesuburan Tanah dan

Pemupukan. USU Pres.

Medan.

Dwi, 2015. Pengaruh Konsentrasi

Zat Pengatur Tumbuh Auksin

Golongan NAA Dan Waktu

Penyiangan Terhadap

Pertumbuhan Dan Hasil

Kacang Hijau (Vigna radiate

L.). https:// Bengkulukota.

Bps.go.id /. (2015).

Hadriman Khair, dkk. 2013.

Pengaruh Konsentrasi

Ekstrak Bawang Merah Dan

Air Kelapa Terhadap

Pertumbuhan Stek Tanaman

Melati Putih (Jasminum
Sambac L.). Program Studi Agroekoteknologi Fakultas Pertanian UMSU Medan.

Kristina, N. N dan S F SYAHID. 2012.

Pengaruh Air Kelapa

Terhadap Multiplikasi Tunas

In Vitro, Produksi Rimpang

dan Kandungan

Xanthorrhizol Temulawak Di

Lapangan. Jurnal Littri 18(3), 125-134.

Lestari, G. Endang. 2011. Peranan

Zat Pengatur Tumbuh Dalam

Perbanyakan Tanaman

Melalui Kultur Jaringan.

Balai Besar Penelitian dan

Pengembangan Bioteknologi

dan Sumberdaya Genetik

Pertanian. Bogor.

Mareza E. Podesta F. dan Ratibayati, 2009. Respon Perkecambahan Lima Varietas Padi Rawa Lebak Terhadap Pemberian Zat Pengatur Tumbuh 2,4-D pada Fase Vegetatif di Lapangan. Akta Agrosia Vol. 12 No. 2 hlm 177-183.

Fakultas Pertanian.

Universitas IBA. Palembang.

Marfirani, Melisa.dkk.2014.

Pengaruh Pemberian

Berbagai Konsentrasi Filtrat

Umbi Bawang Merah dan

Rootone-F terhadap

Pertumbuhan Stek Melati

"Rato Ebu".Lentera Bio 3 (1) : 73-76.

Miyasaka, S. C., R. T. Hamasaki and Ramon, S. 2002. Nutrient Deficiencies and Excesses in Taro. University of Hawai'i. Manoa. Pp.14.

Murkalina, dkk. 2013. Pertumbuhan stek Melati Putih (Jasminum sambac (L) W. Ait)dengan pemberian air 
kelapa danIBA (Indole Butyric Acid). Mufti, 2015. 'Pengaruh frekuensi pemberian konsentrasi rhizobakteri pemacu pertumbuhan tanaman terhadap pertumbuhan dan hasil (Glycine Max L.

Merrill)'.'Fakultas Pertanian.

Universitas Brawijaya. Malang.

Nurlaeni, Y. dan Syrya, M.I. 2015. Respon Stek Pucuk Camellia Japonica Terhadap Pemberian Zat Pengatur Tumbuh Organik. Jurnal Sem Nas Masy Biodiv Indon. 1(5) : 1211-1215.

Pacheco, G., Garcia, R., Lugato, D., Vianna, M.\& Mansur, E. (2012) Plat Regeneration, Cullus Induction and Establishment of Cell Suspension Cultures of Passiflora alata Curtis. Scienta Horticultura. 144, 4147.

Doi:101016/j.scinta.2012.06. 022.

Padjar,M.2010.Varietaskedelai.http:/ dedenia.Wordpress.com/2009 /09/002/varietaskedelaisoybea n-part-1/html.

[13 September 2014].

Padjar.2010.Kedelaisetelahsatudeka d e.Majalah.tempo.http://majala h.tempointeraktif.com/id/arsi p/2010/03/29/EB/mbm.010.i d .html. Diakses pada tanggal 5 Juli 2015.

Permadi, K. 2014. Implementasi pupuk N, P, dan K untuk mendukung Swasembada kedelai. Balai

pengkajian
Pertanian Jawa Barat.
AGROTROP, 4 (1): 1-
6.

Podesta fiana, 1997. Masukan Jumlah Energi Panas dan Konsentrasi 2,4-D Terhadap Hasil, Mutu Benih dan

Kualitas Gizi Kedelai (Glycine $\max$ L. Merrill). Tesis. Program Pasca Sarjana Universitas Andalas. Padang.

Rajiman, 2018. Pengaruh Zat Pengatur Tumbuh (ZPT) Alami Terhadap Hasil Dan Kualitas Bawang Merah.

Simanjuntak, D. Peranan Trchoderma, Micoriza dan Pospat terhadap Tanaman Kedelai pada Tanah Sangat Masam (Humitropets). J. penelitian bidang ilmu pertanian, 3(1), 36-42.2005.

Siskawati, E., L. Riza., dan Mukarlina. 2013. Pertumbuhan stek batang jarak pagar (Jatropha curcas L.) dengan perendaman larutan bawang merah (Allium cepa 1 .) dan IBA

(Indol Butyric Acid). J. protobiont 2(3):167-170.

Siswanto, U., N.D. Sekta, dan A.

Romeida. 2010. Penggunaan auksin dan sitokinin alami pada pertumbuhan bibit lada panjang (piper retrofractum vah L.). Tumbuhan Obat Indonesia volume 3(2):128132.

Sudaryanto, T, dan D,K. Swastika. 2007. Elonomi Kedelai di Indonesia. Dalam: kedelai: 
Teknik produksi dan pengembangan. Sumarno, Suyamto, A. Witjono, Hermanto, dan H, Kasim (Eds). Puslitbangtan, Bogor.

Sukmawati, 2013. Respon tanmaman kedelai terhadap pemberian pupuk organic ditanah pasiran. Media Bina Ilmiah Volume 7, no. 4. Juli 2013.

Surtinah, 2018.

Korelasi

pertumbuhan organ vegetatif dengan produksi kedelai (Glycine max L. Merrill).

Sutomo, 2011. Budidya Tanaman

Kedelai Unggul. http://www. gerbangpertanian. com/2010/04/budidayatanama n-kedelai-unggul.html. Diakses tanggal 25 Oktober 2011.

Susio, I.B. 1996. Pengaruh lama perendaman dan dosis penyiraman limbah air kelapa terhadap pertumbuhan Corm Gladiol (Gladiolus hibridus Var. Dr Manseor). Skripsi tidak diterbitkan. Malang: Fakultas Pertanian.

Universitas Muhammadiyah Malang.

Wattimena, G.A. 1988. Zat Pengatur

Tumbuh Tanaman.

Laboratorium Kultur

Jaringan Tanaman PAU

Bioteknologi IPB. Bogor. 145 hlm.

Widyastuti, N. dan D.

Tjokrokusumo, 2006.

Pernanan beberapan zat

pengatur tumbuh (ZPT)

Tanaman pada Kultur In
Vitro. Jurnal Saint dan Teknologi BPPT.

V3. N5. 08.

Zahrah, S. 2011. Respon Berbagai Varietas Kedelai

(Glycine $\max$ l. Merrill) terhadap Pemberian Pupuk NPK Organik. J. Teknobiol.2(1): 65-69. 